\title{
Fertility Indicators with Hill-Valley Variations in Manipur
}

\author{
${ }^{1}$ M. Damudor Singh ${ }^{2}$ N. Sharat Singh \\ ${ }^{1}$ Assitant Prof. in Geography, Thoubal College, Thoubal (Manipur-795138) \\ ${ }^{2}$ Dept. of Statistics, Thoubal College (Manipur-795138)
}

\begin{abstract}
Since seventy years of Indian independence, the northeast states are nowhere near a satisfactory solution in terms of socio-demographic development. It is more prevalent in Manipur, the easternmost state internationally bordering with Myanmar (Burma). With a unique feature that "a maximum number of dialect with least number of population", the tribal people here are having more serious demographic imbalances than other tribes in the country. Under research question - 'what are the levels of fertility indices of women residing in valley and hill areas?' it is to investigate the regional variations in the fertility indicators between hill and valley populations in Manipur. An empirical study was conducted under cross sectional survey design during the eight months period from May, 2015 to December, 2015 taking 1335 eligible women having at least one live birth under cluster sampling scheme in two districts of Manipur in such one in valley - Thoubal, and other in hill - Chandel. In addition to classical statistical tests, regression models are utilized to identify the causal factors of the differentials in the fertility indices. Statistically significant variations have been reported in age at marriage, desire of son, post partum amenorrhoea, contraceptive uses etc. each at $\mathrm{P}<0.001$ and also in age at menarche, infant and child mortality, still birth, age at menopause etc. each at $\mathrm{P}<0.01$. The processing of these significant indicators at a level consistent with the national target of stable population in India is highly needed to have a linkage with social development.
\end{abstract}

Keywords: age at marriage, sex preference, contraceptive, regression models, $P$-value.

\section{INTRODUCTION}

Following Cairo's International Conference on Population and Development (ICPD-1994) in its expansion of Programme of Action (PoA) from a sole concern with fertility reduction, India's National Population Policy (NPP) - 2000 had formulated the short, medium and long term objectives. While the medium-term objective is to bring the total fertility rate to replacement level (2.1) by 2010, its long-term objective is to achieve a stable population by 2045 , at a level consistent with the requirements of sustainable economic growth, social development, and environmental protection. The policy also gives special attention to the tribal and backward communities and recommends special provisions for health services and the treatment of infertility among them in view of the fact that many tribal communities are dwindling in numbers. A good number of past findings observed that the fertility level of rural as well as hill community could not be reduced to national level. It is associated with the factors like low socio-economic status, disadvantages of communication and infrastructures etc (Bhagat and Chattopadyay, 2004; Nanda, 2005; Saha and Verma, 2006). Even after six decades of having national population policy in our country, fertility rates are higher for women in disadvantage groups say for instance 3.1 children per women among schedule tribes, 2.9 among scheduled castes, and 2.8 among other backward classes, compared with women who are not any of these groups (2.4 children) while its all India figure of 2.7 (IIPS, 2008). The 2001 Census in India classified more than eight percent population of the country or 84.32 million people as scheduled tribes, which is more than the population of Germany or the combined population of France and Australia. This motivated us to research whether fertility in this large socio-economically deprived group is consistent with mainstream of Indian society, or which is experiencing a rapid, decline in fertility. Thus past studies indicate that strengthening the Reproductive \& Child Health ( $\mathrm{RCH})$ services in tribal/ hill areas specifically targeting young tribal mothers is need of the hour. Promotion of larger inter-birth intervals by generating demand for family planning services particularly the uses of spacing methods and reduction of the gender preference for children by intervention of (IEC) in tribal areas are also required. In the meantime, higher fertility transition or so term as the $3^{\text {rd }}$ birth transition is a serious demographic phenomenon to population growth. Lack of education and son preference may be sole responsible to it. The past studies conducted in India have identified three major factors for son preference. They are economic, socio-cultural and religious utilities. Sons are more likely than daughters to provide family labour on the farm or in family business and support their parents of old age, although there is some recognition that sons are no longer a dependable source of old age support (Mason, 1992; Dharmalingam, 1996; Nath and Deka, 2004). A son brings upon marriage a daughter-in-law into his family and she provides 
additional help around the house as well as an economic reward in the form of dowry payments. In the context of India's patriarchal family system, having one son is imperative for continuation of the family line, and many sons provide additional status to the family (Moore, 1994). The utility of having sons also arises from the important religious functions that only sons can provide (Nath and Leonetti, 2001). According to Hindu tradition, sons are needed to kindle the funeral pyre of their deceased parents and to help in the salvation of their souls. Most of the Indian couples have thus a strong preference for sons over daughters. In an effort to have sons, many couples continue to have children after achieving their desire family size. In case of intention, about $20 \%$ of Indian couples want more sons than daughters, but only 2 to $3 \%$ of them want more daughters than sons (IIPS, 2007). In Manipur, 31.2\% of ever married women who want more sons than daughters according to NFHS-3:2005-06 which is declining from that of 36.5\% in NFHS-2:1998-99 and 43.4\% in NFHS1:1992-93(IIPS, 2008).

\section{OBJECTIVES}

It is to investigate the fertility indicators in Manipur. Specifically, the present investigation is to examine the regional variations in the fertility indicators between hill and valley populations and determinants of higher fertility transition in the population.

\section{MATERIALS AND METHODS}

A community based study was conducted under cross sectional mode during the eight months period from May, 2015 to December, 2015 taking 1355 married women under cluster sampling scheme in two districts of Manipur say Thoubal (valley) and Chandel (hill). The eligible mothers are taken into account after excluding the mother who did not fulfill the condition that - she must have had at least two live births and hence the present analysis is based on 979 illegible women. In addition to classical statistical tests, logistic regression models are utilized to identify the causal factors of the differentials in higher fertility levels. The study population is one of the North Eastern states of India inhabited mainly by the Mongoloid race. The primary data was collected by using a pre-tested and semi-structural interview schedule as a tool for survey. The clusters for instance, rural-urban differential is defined according to Population of Manipur (Directorate of Economics \& Statistics 2008). In this study, the $3^{\text {rd }}$ birth transition is taken as dependent variable. The binary logistic regression model is based on the fact that the dependent variable is dichotomous which is defined to be 1 if the woman has at least $3^{\text {rd }}$ live birth and 0 , the women has at most two live birth. Ten independent variables considered are regional class (hill $=1$, valley=0), educational levels of husband, educational levels of wife, family income, age at marriage of husband, age at marriage of wife, mother's age at $2^{\text {nd }}$ delivery, couple's desire number of son, sex of $2^{\text {nd }}$ live birth (male $=1$, female $=0$ ) and status of sterilization (wife is sterilized $=1$, otherwise $=0$ ). Among the variables, age, income and sex preference defined to be the desire number of son have their quantitative values and hence at present, no difficulties of measurement. For categorical variables - regional class, sex and status of sterilization, binary dummy variable $(0,1)$ is utilized. As the education has no quantitative value leading to some difficulties of measurement so that it has been quantified by the number of completed years in schooling viz., Illiterate $=0$, literate but under matriculate $=5$, matriculate but below ten plus two standard $=10$, ten plus two standard but undergraduate $=15$, graduate and above $=20$. But, in logistic regression analysis the five educational standards are quantified and also interpreted by five levels, say from 1 to 5 . In this analysis, 0.05 and 0.01 levels of Pvalues are used for significance of the test statistics.

\section{ANALYSIS AND RESULTS}

The fertility of hill women (3.1) is found to be significantly higher $(\mathrm{P}<0.01)$ than that of valley women (2.6) while the overall mean fertility of (2.9) in the population. The starting event of reproductive period, the age at menarche varies significantly within the two communities of hill (12.9 year) and valley (13.1 year) shown in Table-1. The current fertility differential might be is linked with significantly lower $(\mathrm{P}<0.05)$ age at marriage of hill women ( 24 year) from valley ( 25 year) and couple's desire number of son in their life time as a parameter of family setups (hill: $1.9>$ valley: $1.7 ; \mathrm{P}<0.05$ ). In this sample data, number of pregnancy is also observed to be higher in valley women (3.46) than hill women (3.32) which inversely associated with the average fertility of valley women (2.59) which is lower than hill women (3.11). It may perhaps be associated with the number of fetal death and abortion. The child mortality rate is also visibly higher in hill community (Son: $0.10 \pm 0.37$ and daughter: $0.06 \pm 0.27$ ) than that of valley (son: $0.07 \pm 0.29$ and daughter: $0.05 \pm 0.28$ ). Out of total number of pregnancies, a woman has about $11 \%$ abortion in the population. But, hill women share only $4.2 \%$ while valley women takes $17.3 \%$. It is estimated from the average number of abortion is $0.37 \pm$ 0.70 corresponding to the number of pregnancy, $3.39 \pm 1.67$. While the average number of abortion per hill woman is observed to be $0.14 \pm 0.40$, the corresponding figure of valley woman is $0.60 \pm 0.0 .84$. Thus, number of abortion for hill women is significantly lower than that of valley $(\mathrm{P}<0.01)$. While the duration of 
PPA for first birth is 4.96 months, hill women have significantly shorter duration of 3.77 months than that of valley (6.17). Irrespective of parity, the PPA for last birth in hill women (4.41) have also shorter $(\mathrm{P}<0.01)$ than valley women (6.23). As the last event of women's reproductive span, the age at menopause is observed to be 47.51 years, it is significantly earlier $(\mathrm{P}<0.05)$ in hill women $(46.39$ years $)$ than valley women $(48.51$ years). In view of these indicators, hill couples may be observed to be far lagging behind the prevalence of birth control practices used by valley couples in the population.

Out of 979 eligible women, about $50 \%$ that is 489 women are found to have their third birth in the population. A binary logistic regression analysis on the transition of third birth ( 1 if at least $3^{\text {rd }}$ birth occurred, 0 otherwise) is carried out to identify the determinants thereof. In the multiple logistic regression models, only three out of the ten independent variables can be detected to have their significant impacts on the $3^{\text {rd }}$ birth transition in the population. The adjusted OR levels of the variables with their 95\% CI are manifested in Table-2. The significant factors found in the model are age at $2^{\text {nd }}$ delivery of wife $(\mathrm{P}<0.01, \mathrm{OR}=0.83)$, couples' desire number of son $(\mathrm{P}<0.01, \mathrm{OR}=3.95)$ and sex of $2^{\text {nd }}$ live birth $(\mathrm{P}<0.05, \mathrm{OR}=0.55)$. Age at $2^{\text {nd }}$ delivery of wife and sex (male) of $2^{\text {nd }}$ live birth are negatively as well as significantly associated with $3^{\text {rd }}$ birth transition. But, the behavioural factor - couples' desire number of son is positively and highly significantly related with the serious phenomenon of $3^{\text {rd }}$ birth. The level of significance of each contributed variable is observed after adjusted or keeping constant the joint effects of other nine background variables under study.

Applying stepwise method in the logistic regression the determinants of $3^{\text {rd }}$ birth transition is found to be five factors. In other words, only five independent variables have been identified to be elements of the best set of $3^{\text {rd }}$ birth transition. They are couple's desire number of son, age at $2^{\text {nd }}$ delivery, education of husband, sex of $2^{\text {nd }}$ live birth and status of sterilization shown in Table-3. In the last fifth model, the logistic regression is fitted with the five variables. It is to say that the logistic regression model is significant with these five independent variables. After adjusted the joint effects of combination of four other variables in the last model, education of husband, age at second delivery, sex of second baby and status of sterilization of wife are found to be negatively associated with the third birth transition. Among the five determinants, only one factor - the couples' desire number of son has positive impact on the phenomenon. In the last fitted model, keeping constant the effects of four other variables, the risk of having $3^{\text {rd }}$ birth can significantly be reduced $(\mathrm{P}<0.01)$ by $6 \%$ as advancement of one level in husband's education as its OR-value (0.94). One year advance in age at second delivery, the women can be free of $12 \%$ from the risk of $3^{\text {rd }}$ birth in the sense that at an average a woman has $12 \%$ more risk of being $3^{\text {rd }}$ birth with respect to one year earlier of her age at delivery of second live birth $(\mathrm{P}<0.01, \mathrm{OR}=0.82)$. One of the most important findings in this logistic regression analysis is that very high significant risk of 3.7 times of the chance of third birth transition is observed to each increment in the couple's desire number of son as supported by its test values $(\mathrm{P}<0.01, \mathrm{OR}=3.74)$ when the joint effect of other four factors in the last model is typically controlled. The ill habit of son preference effect is again reemphasized that high risk of $3^{\text {rd }}$ birth phenomenon $(\mathrm{P}<0.01)$ can be quantified to be $45 \%$ in the previous $2^{\text {nd }}$ child is female than that of male $(\mathrm{OR}=0.55)$. While adjusted the effects of four variables say couple's desire number of son, age at $2^{\text {nd }}$ delivery, education of husband and sex of $2^{\text {nd }}$ live birth, the chance of having third birth transition can be reduced by $89 \%(\mathrm{P}<0.01)$ if the mother has been sterilized $(\mathrm{OR}=0.19)$.

\section{DISCUSSION}

Only three independent variables are found significant on the transition of third birth in the multiple logistic regression models. It reveals that each age at second delivery $(\beta=-0.18, \mathrm{P}<0.01)$, couples' desire number of son $(\beta=1.37, \mathrm{P}<0.01)$ and sex of second live birth $(\beta=-0.60, \mathrm{P}<0.05)$ has its significant impact on the third birth transition when the joint effects of other nine factors are controlled. As an achievement of stepwise method, five factors can be detected to be determinants of third birth transition in the population. The factors are couple's desire number of son $(\beta=1.41, \mathrm{P}<0.01)$, age at $2^{\text {nd }}$ delivery $(\beta=-0.12, \mathrm{P}<0.01)$, education of husband ( $\beta=-0.06, \mathrm{P}<0.01)$, sex of $2^{\text {nd }}$ live birth $(\beta=-0.60, \mathrm{P}<0.05)$ and status of sterilization ( $\beta=-1.68, \mathrm{P}>0.05)$. In the last model, each of five explanatory variables may be interpreted their effects corresponding to the statistics of regression coefficient - $\beta$, P-value and OR with 95\%CI when adjusted the joint effects of four other variables.

The last fitted logistic regression model of the $3^{\text {rd }}$ live birth transition consists of five independent factors namely couple's desire number of son, age at $2^{\text {nd }}$ delivery, education of husband, sex of $2^{\text {nd }}$ live birth and status of sterilization. These five variables may be treated as the determinants of $3^{\text {rd }}$ birth transition in the population under study. In many Indian societies as the couples are educated, eagerness to restrict the family size increases. The present findings also observe the similar view. But, comparing the effects of education of 
husband with the wife counterpart, it is evident that the education of husband $(\mathrm{P}<0.01)$ plays more significant role in preventing third birth transition. It emphasized that husband's education has more consisted with decision taking of reproduction stopping particularly, of $3^{\text {rd }}$ birth transition under the condition that the effects of four significant factors - couple's desire number of son, age at $2^{\text {nd }}$ delivery, sex of $2^{\text {nd }}$ live birth and status of sterilization are typically controlled. The effects may include delaying age at $2^{\text {nd }}$ delivery, reduction in the desired number of son, increase opportunities for personal advancement, awareness of social mobility and freedom from close familiarities of women outside the home and greater exposure to knowledge and favourable attitude towards family limitations. Thus, enhancement of education is supposed to result in nonfamilial aspiration and a greater understanding of the process and ways of controlling high fertility. This view is supported by the findings of Yadava and Sharma (2004). Again from the event-history analysis of 2000 Egyptian Demographic and Health Survey, Vignoli (2006) stresses that the difficult change in the fertility of women with high educational status seems to be responsible for the stalling fertility decline during recent years.

However, the sex of the previous/ index child is demographic factor which can not be managed by human hand. The value of the OR say 0.55 means that the risk of third birth transition is reduced about double times when the previous child is male than that of female counterpart. While adjusted the joint effects of other four variables in the last model, couple's desire number of son is also observed to be high influential factor $(\mathrm{P}<0.01)$ leading to third birth. It is advocated by OR value of 3.74 which indicates that the risk of third birth is increased by nearly four times corresponding to desire of one more son. It is thought to be caused by the fact that influence of son preference is high in the study population. This view is supported by Singh et al. (2007) and Singh et al. (2011). They found that the duration of waiting time to conception is significantly short as the desire number of son increases. The finding is in agreement with some other past findings too. In many developing countries, reproductive intentions and behaviours are strongly influenced by sex of surviving children. (IIPS, 2007; Hussain et al., 2000; Youssef, 2005; Khawaja and Randall, 2006) This ill behave may have retarded India's fertility decline and therefore the present fertility level is far behind the national socio-demographic goals for replacement fertility 2.1 children.

Acknowledgement: The authors are indebted to University Grants Commission, NERO, India for financial support under Research Project with reference vide sanction No. F.5-266/2014-15/MRP/NERO/3154 dated the $11^{\text {th }}$ March, 2015 from which the present data is used.

\section{REFERENCES}

[1] Bhagat, R. B. and Chattopadhyay, A., 2004, Characteristics and correlates of tribal fertility: A comparative study of selected tribes. Demography India, 33(2): 295-310.

[2] Dharmalingam, A, 1996, The social context of family size preferences and fertility behabiour in a South Indian village. Genus, 52: 83-103.

[3] Hussain, R., Fikree, F. F., Berendes, H. W., 2000, The role of son preference in reproductive behavior in Pakistan. Bulletin of the World Health Organisation, 78(3): 379-388.

[4] International Institute for Population Sciences (IIPS), 2007, National Family Health Survey (NFHS-3): 2005-06, India: Key Findings.

[5] International Institute for Population Sciences (IIPS), 2008, National Family Health Survey (NFHS-3), 2005-06, Manipur: 46.

[6] Khawaja, M. and Randall, A., 2006, Intifada Palestinian fertility and women's education. Genus, LXII (1): $21-51$.

[7] Mason, K. O., 1992, Family change and support of elderly in Asia: What do we know? Asia Pacific Population Journal, 7(3): (East West Centre Reprint Series No. 286).

[8] Nanda, S., 2005, Cultural determinants of human fertility: A study of tribal population in Orissa. Anthropologist, 7(3): 221-227.

[9] Nath, D. C. and Deka, A. K., 2004, The importance of son in a traditional society: How elderly parents see it? Demography India, 33(1): 33-46.

[10] Nath, D. C. and Leonetti, D. L., 2011, Correlates of coital patterns in a traditional Indian society. In: R.C. Yadava (ed). Dynamics of population change (Emerging issues of $21^{\text {st }}$ Century). Shipra Publication, Delhi: 57-67.

[11] Saha, K. B. and Verma., 2006, High fertility among scheduled tribes of Madhya Pradesh. Indian Journal of Medical Research, 123: 89-90.

[12] Singh, N. S., Narendra, R. K. and Hemochandra, L., 2007, Determinants of waiting time to conception in Manipuri women. Kuwait Medical Journal, 39(1): 39-43.

[13] Singh, N. S., Singh, N. S. and Narendra, R. K., 2011, Survival analysis of duration of waiting time to conception. Electronic Journal of Applied Statistical Application, 4(2): 144-154. 
[14] Vignoli, D., 2006, Fertility change in Egypt: From second to third birth. MPIDR Working Paper 2006011.

[15] Yadava, R. C. and Sharma, S. S., 2004, Closed birth interval versus most recent closed birth intervals. Demography India, 33(2): 249-263.

[16] Youssef, R. M., 2005, Duration and determinants of inter birth interval: Community-based survey of women on Southern Jordan. Eastern Mediterranean Health Journal, 11(4): 559-572.

Table-1: Differential of fertility indicators according to hill-valley region

\begin{tabular}{|c|c|c|c|c|c|}
\hline Indicators & $\begin{array}{l}\text { Regional } \\
\text { class }\end{array}$ & $\mathbf{N}$ & Mean \pm S.D & 95\% CI for Mean & P-value for $t$-test \\
\hline \multirow{3}{*}{$\begin{array}{l}\text { Current } \\
\text { Fertility }\end{array}$} & Valley & 489 & $2.59 \pm 1.50$ & $(2.48,2.70)$ & \multirow{3}{*}{$\mathrm{P}<0.01$} \\
\hline & Hill & 490 & $3.11 \pm 1.40$ & $(3.01,3.22)$ & \\
\hline & Total & 979 & $2.85 \pm 1.47$ & $(2.77,2.93)$ & \\
\hline \multirow{3}{*}{$\begin{array}{l}\text { Age at } \\
\text { menarche }\end{array}$} & Valley & 489 & $13.13 \pm 1.31$ & $(13.03,13.23)$ & \multirow{3}{*}{$\mathrm{P}<0.01$} \\
\hline & Hill & 490 & $12.90 \pm 1.08$ & $(12.82,12.98)$ & \\
\hline & Total & 979 & $13.01 \pm 1.21$ & $(12.95,13.08)$ & \\
\hline \multirow{3}{*}{$\begin{array}{l}\text { Age at } \\
\text { marriage of } \\
\text { wife }\end{array}$} & Valley & 489 & $24.96 \pm 4.76$ & $(24.61,25.32)$ & \multirow{3}{*}{$\mathrm{P}<0.05$} \\
\hline & Hill & 490 & $24.25 \pm 4.78$ & $(23.89,24.61)$ & \\
\hline & Total & 979 & $24.61 \pm 4.78$ & $(24.35,24.86)$ & \\
\hline \multirow{3}{*}{$\begin{array}{l}\text { Couple's } \\
\text { desire no. } \\
\text { of son }\end{array}$} & Valley & 489 & $1.73 \pm 0.48$ & $(1.69,1.76)$ & \multirow{3}{*}{$\mathrm{P}<0.01$} \\
\hline & Hill & 490 & $1.92 \pm 0.37$ & $(1.89,1.95)$ & \\
\hline & Total & 979 & $1.82 \pm 0.44$ & $(1.80,1.85)$ & \\
\hline \multirow{3}{*}{$\begin{array}{l}\text { No. of } \\
\text { deceased } \\
\text { son }\end{array}$} & Valley & 489 & $0.07 \pm 0.29$ & $(0.04,0.09)$ & \multirow{3}{*}{$\mathrm{P}>0.05$} \\
\hline & Hill & 490 & $0.10 \pm 0.37$ & $(0.07,0.13)$ & \\
\hline & Total & 979 & $0.08 \pm 0.33$ & $(0.06,0.10)$ & \\
\hline \multirow{3}{*}{$\begin{array}{l}\text { No. of } \\
\text { deceased } \\
\text { daughter }\end{array}$} & Valley & 489 & $0.05 \pm 0.28$ & $(0.03,0.07)$ & \multirow{3}{*}{$\mathrm{P}>0.05$} \\
\hline & Hill & 490 & $0.06 \pm 0.27$ & $(0.04,0.08)$ & \\
\hline & Total & 979 & $0.06 \pm 0.27$ & $(0.04,0.07)$ & \\
\hline \multirow{3}{*}{$\begin{array}{l}\text { No. of still } \\
\text { birth }\end{array}$} & Valley & 489 & $0.10 \pm 0.79$ & $(0.04,0.16)$ & \multirow{3}{*}{$\mathrm{P}<0.01$} \\
\hline & Hill & 490 & $0.01 \pm 0.12$ & $(0.01,0.02)$ & \\
\hline & Total & 979 & $0.06 \pm 0.56$ & $(0.03,0.09)$ & \\
\hline \multirow{3}{*}{$\begin{array}{l}\text { No. of } \\
\text { miscarriage }\end{array}$} & Valley & 489 & $0.14 \pm 0.41$ & $(0.11,0.17)$ & \multirow{3}{*}{$\mathrm{P}>0.05$} \\
\hline & Hill & 490 & $0.12 \pm 0.34$ & $(0.10,0.15)$ & \\
\hline & Total & 979 & $0.13 \pm 0.38$ & $(0.11,0.15)$ & \\
\hline \multirow{3}{*}{$\begin{array}{l}\text { No. of } \\
\text { abortion }\end{array}$} & Valley & 489 & $0.60 \pm 0.84$ & $(0.54,0.67)$ & \multirow{3}{*}{$\mathrm{P}<0.01$} \\
\hline & Hill & 490 & $0.14 \pm 0.40$ & $(0.11,0.17)$ & \\
\hline & Total & 979 & $0.37 \pm 0.70$ & $(0.33,0.41)$ & \\
\hline \multirow{3}{*}{$\begin{array}{l}\text { Total no. of } \\
\text { pregnancies }\end{array}$} & Valley & 489 & $3.46 \pm 1.88$ & $(3.32,3.60)$ & \multirow{3}{*}{$\mathrm{P}>0.05$} \\
\hline & Hill & 490 & $3.32 \pm 1.42$ & $(3.22,3.43)$ & \\
\hline & Total & 979 & $3.39 \pm 1.67$ & $(3.30,3.48)$ & \\
\hline \multirow{3}{*}{$\begin{array}{l}\text { Age at first } \\
\text { delivery }\end{array}$} & Valley & 449 & $25.79 \pm 4.29$ & $(25.46,26.13)$ & \multirow{3}{*}{$\mathrm{P}<0.05$} \\
\hline & Hill & 393 & $25.19 \pm 4.44$ & $(24.86,25.51)$ & \\
\hline & Total & 842 & $25.49 \pm 4.37$ & $(25.26,25.73)$ & \\
\hline \multirow{3}{*}{$\begin{array}{l}\text { Duration } \\
\text { (in mth) of } \\
\text { PPA for } 1^{\text {st }} \\
\text { birth }\end{array}$} & Valley & 449 & $6.17 \pm 4.63$ & $(5.81,6.52)$ & \multirow{3}{*}{$\mathrm{P}<0.01$} \\
\hline & Hill & 393 & $3.77 \pm 2.82$ & $(3.56,3.99)$ & \\
\hline & Total & 842 & $4.96 \pm 4.00$ & $(4.74,5.17)$ & \\
\hline Duration & Valley & 449 & $6.23 \pm 3.96$ & $(5.93,6.53)$ & \\
\hline $\begin{array}{l}\text { (in mth) of } \\
\text { PPA for }\end{array}$ & Hill & 393 & $4.41 \pm 2.61$ & $(4.22,4.61)$ & $\mathrm{P}<0.01$ \\
\hline last birth & Total & 842 & $5.32 \pm 3.47$ & $(5.13,5.50)$ & \\
\hline Age at last & Valley & 449 & $30.34 \pm 5.47$ & $(29.92,30.76)$ & \\
\hline & Hill & 393 & $32.85 \pm 4.57$ & $(32.50,33.19)$ & $\mathrm{P}<0.01$ \\
\hline & Total & 842 & $31.60 \pm 5.19$ & $(31.32,31.88)$ & \\
\hline Age at & Valley & 20 & $48.51 \pm 1.74$ & $(47.70,49.32)$ & $\mathrm{P}<0.05$ \\
\hline
\end{tabular}




\begin{tabular}{|l|l|l|l|l|l|}
\hline menopause & Hill & 18 & $46.39 \pm 3.55$ & $(44.62,48.15)$ & \\
\cline { 2 - 5 } & Total & 38 & $47.51 \pm 2.91$ & $(46.55,48.46)$ & \\
\hline
\end{tabular}

Table-2: Odds Ratios of variables on $3^{\text {rd }}$ births transition in Multiple Logistic Regression

\begin{tabular}{|l|c|c|c|c|}
\hline \multicolumn{1}{|c|}{ Variable } & $\beta$ & $\begin{array}{c}\mathrm{P} \text {-value for } \\
\text { Wald-Test }\end{array}$ & OR(e $\beta$ ) & 95\%CI for OR \\
\hline Regional class - Hill/ Valley & 0.12 & $\mathrm{P}>0.05$ & 1.10 & $0.56-2.18$ \\
\hline Education of husband & -0.04 & $\mathrm{P}>0.05$ & 0.96 & $0.91-1.01$ \\
\hline Education of wife & -0.02 & $\mathrm{P}>0.05$ & 0.98 & $0.93-1.02$ \\
\hline Family income & 0.01 & $\mathrm{P}>0.05$ & 1.00 & $0.97-1.04$ \\
\hline Age at marriage of husband & 0.02 & $\mathrm{P}>0.05$ & 1.02 & $0.96-1.07$ \\
\hline Age at marriage of wife & 0.07 & $\mathrm{P}>0.05$ & 1.07 & $0.95-1.21$ \\
\hline Age at $2^{\text {nd }}$ delivery & -0.18 & $\mathrm{P}<0.01$ & 0.83 & $0.74-0.94$ \\
\hline Desire number of son & 1.37 & $\mathrm{P}<0.01$ & 3.95 & $1.91-8.16$ \\
\hline Sex of $2^{\text {nd }}$ live birth & -0.60 & $\mathrm{P}<0.05$ & 0.55 & $0.32-0.95$ \\
\hline Status of sterilization & -1.48 & $\mathrm{P}>0.05$ & 0.23 & $0.04-1.33$ \\
\hline Constant & 2.17 & $\mathrm{P}>0.05$ & 8.78 & \\
\hline
\end{tabular}

Table-3: Odds Ratios of variables on $3^{\text {rd }}$ birth transition in Stepwise Logistic Regression

\begin{tabular}{|c|c|c|c|c|c|}
\hline Step & Variable & $\beta$ & $\begin{array}{l}\text { P-value for Wald- } \\
\text { Test }\end{array}$ & $\mathrm{OR}(\mathrm{e} \beta)$ & $95 \% \mathrm{CI}$ for OR \\
\hline \multirow[t]{2}{*}{1} & Desire number of son & 1.61 & $\mathrm{P}<0.01$ & 4.99 & $2.58-9.67$ \\
\hline & Constant & -2.34 & $\mathrm{P}<0.01$ & 0.10 & \\
\hline \multirow[t]{3}{*}{2} & Age at $2^{\text {nd }}$ delivery & -0.11 & $\mathrm{P}<0.01$ & 0.89 & $0.84-0.95$ \\
\hline & Desire number of son & 1.42 & $\mathrm{P}<0.01$ & 4.14 & $2.09-8.22$ \\
\hline & Constant & 1.43 & $\mathrm{P}>0.05$ & 4.18 & \\
\hline \multirow[t]{4}{*}{3} & Education of husband & -0.05 & $\mathrm{P}<0.01$ & 0.95 & $0.91-0.98$ \\
\hline & Age at $2^{\text {nd }}$ delivery & -0.11 & $\mathrm{P}<0.01$ & 0.90 & $0.85-0.95$ \\
\hline & Desire number of son & 1.43 & $\mathrm{P}<0.01$ & 4.20 & $2.11-8.37$ \\
\hline & Constant & 1.59 & $\mathrm{P}>0.05$ & 4.92 & \\
\hline \multirow[t]{5}{*}{4} & Education of husband & -0.06 & $\mathrm{P}<0.01$ & 0.94 & $0.91-0.98$ \\
\hline & Age at $2^{\text {nd }}$ delivery & -0.12 & $\mathrm{P}<0.01$ & 0.89 & $0.84-0.94$ \\
\hline & Sex of $2^{\text {nd }}$ live birth & -0.65 & $\mathrm{P}<0.01$ & 0.52 & $0.31-0.89$ \\
\hline & Desire number of son & 1.47 & $\mathrm{P}<0.01$ & 4.33 & $2.14-8.77$ \\
\hline & Constant & 2.16 & $\mathrm{P}>0.05$ & 8.70 & \\
\hline \multirow[t]{6}{*}{5} & Education of husband & -0.06 & $\mathrm{P}<0.01$ & 0.95 & $0.91-0.98$ \\
\hline & Age at $2^{\text {nd }}$ delivery & -0.12 & $\mathrm{P}<0.01$ & 0.88 & $0.83-0.94$ \\
\hline & Sex of $2^{\text {nd }}$ live birth & -0.60 & $\mathrm{P}<0.05$ & 0.55 & $0.32-0.94$ \\
\hline & Desire number of son & 1.41 & $\mathrm{P}<0.01$ & 3.74 & $1.99-7.34$ \\
\hline & Status of sterilization & -1.68 & $\mathrm{P}<0.05$ & 0.19 & $0.03-1.05$ \\
\hline & Constant & 2.44 & $\mathrm{P}<0.05$ & 11.49 & \\
\hline
\end{tabular}

